\title{
Integrative Leadership is a Precursor of Engagement of Bank Employees in Pakistan
}

\author{
Sanober Salman Shaikh (Corresponding author) \\ (Assistant Professor, University of Sind, Pakistan) \\ PhD Candidate, School of Human Resource Development \\ Bangkok 10240, Thailand \\ E-mail: sanobershaikh25@yahoo.com \\ Dr. Chiraprapha Akaraborworn \\ Assistant to President for Quality Development \& \\ Associate Prof, School of Human Resource Development, \\ National Institute Development Administration (NIDA) \\ Bangkok 10240, Thailand. \\ E-mail: chira123@gmail.com
}

Received: July 20, 2017 Accepted: July 31, 2017 Online published: August 11, 2017

doi:10.5296/ijhrs.v7i3.11673 URL: https://doi.org/10.5296/ijhrs.v7i3.11673

\begin{abstract}
The purpose of this study was twofold: to examine the relationship and determine the predictive power of integrative leadership on employee engagement. To achieve the mentioned objectives, the quantitative research method was employed and data was collected through survey questionnaire from 1000 operational employees of all 21 private banks in Pakistan. The sample of 819 respondents was utilized for final analysis. Two stage sampling method was performed; non- probability sampling and stratified random sampling. The data analysis was done by use of correlation and multiple regression. The result indicated a positive correlation among all of the nine constructs of integrative leadership with employee engagement and the six constructs of integrative leadership significantly predicted employees' engagement in private banks in Pakistan. Additionally, analysis of variance was performed to assess the differences in employee engagement among the respondents' demographic characteristics. The ANOVA result showed that the employees working in a
\end{abstract}


conventional and Islamic bank and age 49 and above group, predicted a difference only in the satisfaction dimension of employee engagement. Furthermore, the current bank experience indicated the difference in overall employee engagement. This study adds value to the literature as it contributes empirical evidence on integrative leadership and employee engagement. This study can be helpful for private banks, also for public \& foreign banks and other organizations in Pakistan in adopting integrative leadership for enhancing employee engagement.

Keywords: Integrative leadership, Precursor, Engagement, Employees, Bank, Pakistan.

\section{Introduction}

Junaidi (2015) stated that Pakistani organizations are undergoing a transitional period, witnessing a continuous change in systems, management cultures and philosophy due to global alignment, they are also facing the same human resources challenges as others countries and organizations are facing, such as employee retention, employee turnover, organization development, salary issues, an increase in job mobility, recruiting, training and development, and compensation issues. Thus, the national and international organizations are facing some macro and micro challenges and these challenges have directly or indirectly affected many businesses.

\subsection{Current Scenario of the Banking Sector in Pakistan}

Pakistani banks have to keep up with the pace of changes and face human resource issues. Currently, challenges have brought many changes to the economy and work settings in all industries, including public and private banks in Pakistan (Ahmad, Tariq \& Hussain, 2015; Hanif, Naqvi \& Hussain, 2015). The banking sector is considered the back bone of every economy as it plays an important role in leading the country in the economic world (Hanif, Naqvi \& Hussain, 2015). The banking sector in Pakistan has been contributing to the Pakistani economy and the global financial crises (Batool, 2013). Considering the importance of the banking sector and its contribution in the development of Pakistan, a response to the various challenges and human resource issues several necessary steps have been taken. However, Pakistan as a developing country, has expanded its banking network. State Bank of Pakistan (2015) stated there are five public sector commercial banks, four specialized scheduled banks, 21 private local banks and five foreign banks. A meticulous look at the Pakistani banking sector makes it quite evident that the banks have been confronted with human resource problems such as employee retention, employee loyalty (Khan, Rehman, Rehman, Safwan, \& Ahmad, 2011), low job satisfaction, lack of organizational commitment and low employee engagement (Hanif, Naqvi \& Hussain, 2015), increased employee turnover (Rashidi \& Rahman, 2013; Alvi \& Abbasi, 2012; Hunjra, Ali, Chani, Khan \& Rehmen, 2010). Hence employee engagement seems to be an issue for banking sector in Pakistan. Employee engagement is considered as a key indicator for the success of the Pakistani banks and other organizations because engaged employees' leads to significant outcomes in Pakistani banks (Rasheed, Khan\& Ramzan, 2013). Gowri and Mariammal (2012) specified that in order to help banks to reap the benefits of sustainability, productivity and increased efficacy; the banks essentially require an engaged workforce. Researchers (Ariani, 2014; Khan, Asghar \& 
Zaheer, 2014; Zhang, Avery, Bergsteiner \& More, 2014; Anwar, 2013; Iqbal, Javaid, Ahmad \& Ateeq, 2013; Gul, Rehman, Razzaq, Ahmad \& Saif, 2012; Raja, 2012; Gul, Ahmad, Rehman, Shabir \& Razzaq, 2012; Riaz, Akram \& Ijaz, 2011; Tims, Bakker \& Xanthopoulou, 2011; Xu \& Thomas, 2011; Yasin Ghadi, Fernando \& Caputi, 2011) claimed that leadership is a fundamental antecedent of employee engagement. Abbas and Yaqoob (2009) indicated that there is a need to examine the leadership development, ways of development and its influence on workers and workplaces in Pakistan. Leadership development is important to perform the job effectively and innovatively by a leader and to increase the managerial capability to gain competitive advantage (Abbas \& Yaqoob, 2009). Leadership development can be achieved through various types of learning and leaders can influence the people and motivate them (Popper, 2005). Currently the leadership researchers are more interested in developing and testing integrative leadership models which synthesizing the existing literature on leadership effectiveness (Fernandez, Cho \& Perry, 2010). Several researches have been done integrative leadership and its relationship with workplace outcomes (Njoroge, 2015; Fernandez, Cho \& Perry, 2010; Morse, 2010; Silvia \& McGuire, 2010; Fernandez, 2005; Van Wart, 2005; Yukl, 2002).

In order to respond the problems of low engagement and its aspect; faced by banking sector in Pakistan, several research has been done in the area of employee engagement in the Pakistani private, public and foreign banks such as (Ajaz \& Mehmood, 2015; Hanif, Naqvi \& Hussain, 2015; Hassan, Hassan, Khan, Aslam, Ahmed \& Iqbal, 2013; Rasheed, Khan \& Ramzan, 2013; Alvi \& Abbasi, 2012; Saleem, Hussain \& Saleem, 2012; Bushra Usman \& Naveed, 2011; Khan, Aslam \& Lodhi, 2011; Mohsan, Nawaz, Khan, Shaukat \& Aslam, 2011; Khattak, Khan, Haq, Arif \& Minhas, 2011). To explore the relationship of different leadership styles with various facets of employee engagement. Some research (Khan, Asghar \& Zaheer, 2014; Anwar, 2013; Batool, 2013; Iqbal, Javaid, Ahmad \& Ateeq, 2013; Raja, 2012; Bushra Usman \& Naveed, 2011; Riaz, Akram \& Ijaz, 2011) has also been done in banking sector in Pakistan. Despite having the important theoretical and managerial contributions of the above-mentioned studies in the context of Pakistan, these studies have certain limitations. Studies conducted on leadership and its relationship with employee engagement in banking sector in Pakistan have focused on single leadership styles, most studies investigated the transformational and transactional leadership styles, inadequate research is available on other leadership styles. Over all, there is quite thin research conducted on integrative leadership and its effect on workplace outcomes. Leadership integration and its relationship with employee engagement in the context of Pakistan is ignored. The researchers suggested that leadership is pivotal for accomplishing and creating employee engagement. The term integrative leadership is becoming more popular in scholarly leadership literature. Therefore, keeping the view of the above mentioned scenario of the Pakistani banking industry, this study is a step forward for the objectives to cultivate the concept of integrative leadership with employee engagement in the context of the private banking sector in Pakistan.

\subsection{Research Objectives}

i. To examine the relationship of integrative leadership with employee engagement in private banking sector of Pakistan. 


\section{MInstitute Macrothink $^{m}$}

International Journal of Human Resource Studies

ISSN 2162-3058

2017, Vol. 7, No. 3

ii. To examine the constructs under integrative leadership predicting employee engagement in the private banking sector of Pakistan.

\subsection{Significance of the Study}

The effective implication of this study is that it may benefit to the Human Resource (HR) researchers, executives and managers of private banking practitioners, other bank's officials, HR professional and managers of other organizations.

\section{Literature Review}

This section of the paper explains the review of literature conducted for this study.

\subsection{Leadership}

Leadership has been defined within many different styles, and definitions differ in many respects, as no single and particular definition of leadership seems to cover every situation (Yukl, 2010), who defines leadership as "the process of influencing others to understand and agree about what needs to be done and how to do it, and the process of facilitating individual and collective efforts to accomplish shared objectives" (p. 8). Javaid and Mirza (2013) opined that "Leadership is a process by which one individual motivates or influences others to achieve organization goals. It is the process of enhancing and encouraging the self-esteem of employees to achieve organizational tasks and goals (p.3). Leadership has been defined in different terms, such as personality traits, behaviors, power, interaction and communication patterns, role or job relationships, and the work of an administrative position (Yukl, 2010).

\subsubsection{Integrative Leadership}

The history on leadership conveys the different clusters of theories, models, approaches, different concepts and definition on leadership; each describes its different dilemma (Fernandez, Cho \& Perry, 2010). But recent leadership researchers have expanded the leadership theories and developed the integrative leadership concept. Some of the definitions and framework of integrative leadership are presented here. "Integrative leadership embraces the leadership skills, traits, behaviors and styles and situational variables, which describes the effectiveness of a leaders (Yukl, 2002). The integrative leadership is defined as a "multidimensional process where leaders perform various roles and behaviors and a combination of three characteristics, such as trait, skills and attitude", consisting of nine constructs: self-awareness and self-regulation leadership, task-oriented leadership, employee concern and integrity leadership, courageous leadership, encouraging and supportive leadership, being a role model leadership, developing others leadership, accessibility focus and personal values leadership, empowerment and care leadership. (Shaikh, Akaraborworn \& Sorod, 2017, p.118-119). Further it is defined as "Integrative leadership is a shared activity, with shared responsibility" (Alban-Metcalfe \& Alimo- Metcalfe, 2010, P.4). Alban-Metcalfe and Alimo- Metcalfe (2010) revealed that integrative leadership is a called shared and collective leadership, in which the person succeeds by collaborative working with one another. Crosby and Bryson (2010) define the integrative leadership as "Bringing together diverse groups and organization in semi-permanent ways and typically across sector 
boundaries- to remedy complex public problems ad achieve the common good (p. 211). Fernandez, Cho and Perry (2010) stated that "integrated leadership is grouping of leadership characters and roles performed by combine efforts of followers at different levels of hierarchy.

\subsection{Different Approaches of Employee Engagement}

Employee engagement has been conceptualized within the context of work and organizational related attitudes and behavior (Herbert, 2011; Saks, 2006). There is no particular definition of engagement, and researchers have defined the term in different ways, so engagement is also being utilized and measured in distinct ways in organizations (Shuck, 2011; Shuck \& Wollard, 2010). There are several definitions of engagement given in the literature, four basic approaches of employee engagement are: (1) Kahn's (1990) need-satisfying approach, (2) Maslach, Schaufeli and Leiter's (2001), burnout-antithesis approach, (3) Harter, Schmidt and Hayes' (2002) satisfaction-engagement approach, and (4) Saks's (2006) multidimensional approach. An explanation of each perspective of employee engagement is as follows.

\subsubsection{Kahn’s (1990) Need-satisfying Approach (Personal Engagement)}

Kahn (1990) defined engagement as "the harnessing of organization members' selves to their work roles; in engagement, individuals at work place utilize and articulate themselves physically, cognitively, and emotionally during the performance". Disengaged employees displayed deficiency in role performances and did not make an effort (Kahn, 1990, p. 964) cited in Kular, (Gatenby, Rees, Soane \& Truss, 2008). Kahn (1992) expanded theory of engagement. The expansion elucidated the concept of psychological domain and its dimensions (meaningfulness, safety, and availability) and their impact on personal engagement (physically, cognitively, and emotionally). Kahn (1992, p.705) defined the dimensions of psychological domains as: meaningfulness is the positive "sense of return on investments of self in role performance." Safety is the ability to show one's self without fear of negative consequences to self-image, status or career; and availability is the "sense of possessing the physical, emotional, and psychological resources necessary to complete one's work" cited in (Shuck, 2010).

\subsubsection{Maslach, Schaufeli and Leiter (2001) Burn-out Engagement Approach}

Maslach and Leiter (1997) define engagement as the affirmative direct opposite to burnout: feeling energetic, being involved, or "a persistent positive effective state; characterized by high levels of activation and pleasure" (Maslach, Schaufeli \& Leiter, 2001, p. 417). As opposed to feeling exhausted, cynical, and ineffective. They define exhaustion (low energy), as "being overextended and depleted of one's emotional and physical resources"; cynicism (low involvement) as "a negative, callous, or an excessively detached response to various aspects of the job"; and ineffectiveness (low efficacy) - the direct result of exhaustion and cynicism - as feelings of incompetence and lack of achievement and productivity at work (cited in Shuck, 2010; Simpson, 2009). Maslach, Schaufeli and Leiter (2001) stated that there are six aspects of work-life that are connected to either burnout or engagement. They recommended that job engagement is associated with a sustainable workload, feelings of 
control, suitable recognition and reward, a supportive work environment, fairness and justice, and meaningful and valued work. Later, the concept was elaborated further, that work engagement defied as positive, fulfilling, work-related state of mind that is characterized by vigor, dedication and absorption (Schaufeli, Salanova, Gonzalez-Roma \& Bakker, 2002).

\subsubsection{Harter, Schmidt and Hayes (2002) Satisfaction-Engagement Approach}

Harter, Schmidt and Hayes (2002) describe employee engagement as occurring when individuals are emotionally connected to others and cognitively vigilant, employee engagement is assumed that "the individual's involvement and satisfaction as well as enthusiasm for work (p. 269)" as cited in (Simpson, 2009). In the model of employee engagement explained by (Harter, Schmidt \& Hayes, 2002), four elements are necessary for engagement to occur within the workplace: (a) clarity of expectations and basic materials and equipment being provided, (b) feelings of contribution to the organization, (c) feeling a sense of belonging to something beyond oneself, and (d) feeling as though there are opportunities to discuss progress and grow.

\subsubsection{Saks’s (2006) Multidimensional Approach}

Sak's (2006) definition of employee engagement emerged from a multidimensional perspective. This definition includes points from previous literature suggesting that employee engagement was developed from cognitive (Maslach, Schaufeli \& Leiter, 2001; Kahn, 1990), emotional (Harter, Schmidt \& Hayes, 2002; Kahn, 1990), and behavioral elements (Harter, Schmidt \& Hayes, 2002; Maslach, Schaufeli \& Leiter, 2001; Kahn, 1990) and extends thoughts on employee engagement by developing a three-component model. Saks (2006) defines "a distinct and unique construct consisting of cognitive, emotional, and behavioral components (p. 602)". Saks' (2006) study proposed that antecedent variables such as supportive management, support from co-workers, job characteristics, reward, recognition and fairness, influenced the development of engagement and that employee engagement mediated the relationship between antecedent and outcome variables. Saks (2006) found a distinction between two types of engagement: job engagement and organization engagement, which he argues are related but distinct constructs. According to Saks (2006), a theoretical rationale to explain employee engagement can be found in the social exchange theory (SET). One way for individuals in organizations to repay their organization is through their level of engagement. Saks (2006) claimed that employees may want to engage in response to the various resources they receive from their organization.

Vance (2006) stated that companies measure employee engagement with ten of the most common themes. These include pride in the employer, satisfaction with the employer, job satisfaction, opportunity to perform well in challenging work, recognition and positive feedback for one's contributions, personal support from one's supervisor, effort above and beyond the minimum, understanding the link between one's job and the organization's mission, prospects for future growth with one's employer, and the intention to stay with one's employer. Fine, Horowitz, Weigler and Basis (2010) measured employee engagement with three dimensions e.g. satisfaction, commitment and discretionary effort. The literature on the 
term 'engagement' is intricate, but each theory which has tested this has some value and makes a contribution towards the literature.

\subsection{Leadership and Employee Engagement}

The term leadership is multidimensional. Despite being a complicated construct, leadership appears to be one of the major factors affecting employee engagement (Macey \& Schneider, 2008). There is strong conceptual support for leadership and employee engagement (Tomlinson, 2010; Batista-Taran, Shuck, Gutierrez \& Baralt, 2009; Gebauer \& Lowman, 2008; Seijts \& Crim, 2006). There is also empirical evidence for the relationship between various leadership styles and different dimensions of employee engagement in different aspects of life including academic, military, health, and banks, as well private and public work settings. Some research papers discuss transformational leadership as positively related to job satisfaction, organizational commitment, and work engagement (Batool, 2013; Bushra, Usman \& Naveed, 2011; Tims, Bakker \& Xanthopoulou, 2011; Alban-Metcalfe \& Alimo-Metcalfe, 2007), transformational and transactional leadership is correlated with job satisfaction and organizational commitment (Khan, Asghar \& Zaheer, 2014; Javaid \& Mirza, 2013; Gul, Ahmad, Rehman, Shabir \& Razzaq, 2012; Raja, 2012; Yasin Ghadi, Fernando \& Caputi, 2011). Servant and transformational leadership is associated with organizational commitment and job satisfaction (Gul, Rehman, Razzaq, Ahmad \& Saif, 2012), classical, transactional, visionary and organic leadership is associated with employee engagement (Zhang, Avery, Bergsteiner \& More, 2014) and there are some separate studies on leadership behaviours which examined leadership relationships and leadership behaviors with employee engagement (Ariani, 2014; Iqbal, Javaid, Ahmad, \& Ateeq, 2013; Xu \& Thomas, 2011; Papalexandris \& Galanaki, 2009). Some unpublished Masters and PhD theses state that ethical leadership is directly related to job satisfaction, organizational commitment and organizational citizenship behavior (Siegel, 2013; Van Foeken, 2010), authentic leadership has associations with job satisfaction, organizational commitment and OCB (Van Foeken, 2010). The above-mentioned studies can be used as a foundation for this study.

\subsection{Respondents' Demographic characteristics and Employee Engagement}

Several past studies (Zhang, Avery, Bergstiener \& More, 2014; Avery, McKay \& Wilson, 2007; 4-Consulting, DTZ Consulting \& Research, 2007; Antoniou, Polychroni \& Vlachakis, 2006; Robinson et al., 2004; Crossman, Abou Zaki, 2003; Jalal Sarker, Crossman \& Chinmeteepituck, 2003; Rothbard, 2001; Oshagbemi, 2000a; Oshagbemi, 2000b; Allen, Poteet \& Russell, 1998; Metle, 1997; Savery,1996; Lee \& Wilber, 1985; Hulin \& Smith, 1965) have reported that certain demographic variables have a significant impact on various dimensions of employee engagement. Therefore, it is important to examine the differences in employee engagement due to the respondents' demographic characteristics.

\subsection{Research Framework}

The research framework of this study was consisting two main variables. The integrative leadership (independent variable) was conceptualized from (Shaikh, Akaraborworn \& Sorod, 2017) and employee engagement (dependent variable) was conceptualized as employees' 
involvement and commitment, satisfaction, energy and absorbed/happiness. Employees' involvement refers to being strongly involved in work and the organization, experiencing a sense of passion, zeal and happiness, whereas commitment is loyalty to the job and the organization. The term satisfaction means that employees feel satisfied with their work and work environment characteristics and also feel proud of their organization. The term energy (vigor) means energy and high levels of activation and being full of emotional and physical resources in every circumstance. Lastly, absorbed/happy refers to contentment with high levels of concentration, happiness and pleasure for work. Employee engagement was conceptualized from the reviewed literature (Fine et al., 2010; Vance, 2006; Saks, 2006; Harter, Schmidt \& Hayes, 2002; Schaufeli et al., 2002; Maslach, Schaufeli \& Leiter, 2001; Kahn, 1990). In addition, in this study, five respondents' demographic variables (bank type, age, gender, current banking experience and education) were taken to examine the differences in employee engagement.

\section{Research Design and Methodology}

This study was designed on the assumption of a positivistic paradigm, hypothetic-deductive approach and the quantitative research method.

\subsection{Sampling}

The target population of this study was operational staff, such as business development officers, junior officers, universal tellers, personal bankers, credit officers, trade officers, remittances officers, clearing officers, accounts opening officers, collection officers, auto teller machine in charge, and relationship officers. In this study two stages of sampling procedure was performed: (1) non-probability sampling and (2) stratified random sampling. The sample size of this study consists of 1000 employees (middle level/operational staff) working in all the 21 private domestic sector banks. The respondents were selected from the three types of banks (Islamic, conventional, and combined Islamic and conventional).

\subsection{Measurement Scale}

The scale of integrative leadership (Shaik, Akaraborworn \& Sorod, 2017) was adopted; consisting of nine constructs and 58 items with Cronbach alpha (.982). The items of employee engagement were taken from (Fine et al., 2010; Sak's, 2006; Schaufeli et al., 2002). The items of employee engagement were revised.

\subsection{Data Collection Method}

The data was collected through questionnaire, survey questionnaire was administered through the internet, mail and personal meetings with participants. The survey questionnaire was comprising of three parts: demographic information, integrative leadership and employee engagement. The constructs were measured by items, using the 6-point likert scale, ranging from 1 (strongly disagree) to 6 (strongly agree). Extensive literature was done to develop the constructs and its items. 


\section{Macrothink \\ International Journal of Human Resource Studies \\ ISSN 2162-3058 \\ 2017, Vol. 7, No. 3}

\section{Data Analysis, Results and Discussion}

\subsection{Data Analysis and Results}

The Pearson correlation analysis was performed to validate the relationship of integrative leadership with employee engagement. The hypothesis was developed H1: there were positive relationships of integrative leadership with employee engagement in the private banking sector in Pakistan. The results supported H1 ( $\mathrm{r}>.335, \mathrm{p}<0.05$, see table 1). The highest correlation was found in self-awareness with employee engagement. The lowest correlation was found in empowerment and care with employee engagement.

Table 1. Results of the Correlation of Integrative Leadership Constructs with Employee Engagement

\begin{tabular}{|c|c|c|c|c|c|}
\hline Independent Variable & \multicolumn{5}{|c|}{ Dependent variable } \\
\hline Integrative Leadership & Employee & $\begin{array}{c}\text { Absorption } \\
\text { and }\end{array}$ & & $\begin{array}{c}\text { Involvement } \\
\text { and }\end{array}$ & \\
\hline Constructs & Engagement & Happiness & Energetic & Commitment & Satisfaction \\
\hline $\begin{array}{l}\text { Self-Awareness/Self-Reg } \\
\text { ulation Leadership }\end{array}$ & $.611 * *$ & $.509 * *$ & $.550 * *$ & $.581 * *$ & $.555^{* *}$ \\
\hline Task- Oriented & & & & & \\
\hline Leadership & $504 * *$ & $.425 * *$ & $.434 * *$ & $.507 * *$ & $.446 * *$ \\
\hline Employee Concern and & & & & & \\
\hline Integrity Leadership & $.467 * *$ & $.431 * *$ & $.443 * *$ & $.451 * *$ & $.399 * *$ \\
\hline Courageous Leadership & $.553 * *$ & $.455^{* *}$ & $.490 * *$ & $.532 * *$ & $.514 * *$ \\
\hline Encouraging and & & & & & \\
\hline Supportive Leadership & $.564 * *$ & $.486 * *$ & $.502 * *$ & $.533 * *$ & $.529 * *$ \\
\hline Being a Role Model & & & & & \\
\hline Leadership & $.431 * *$ & $.357 * *$ & $.407 * *$ & $.415^{* *}$ & $.381 * *$ \\
\hline Developing Others & & & & & \\
\hline Leadership & $.487 * *$ & $.447 * *$ & $.449 * *$ & $.444 * *$ & $.455^{* *}$ \\
\hline Accessibility Focus and & & & & & \\
\hline Personal Values & & & & & \\
\hline Leadership & $0.515^{* *}$ & $0.467^{* *}$ & $0.468^{* *}$ & $0.508^{* *}$ & $0.442 * *$ \\
\hline Empowerment and Care & & & & & \\
\hline Leadership & $0.428^{* *}$ & $0.337 * *$ & $0.402^{* *}$ & $0.412 * *$ & $0.362^{* *}$ \\
\hline
\end{tabular}

The current study examined the integrative leadership predicting employee engagement, the multiple hierarchical regression was performed to examine the predictive power of nine constructs of integrative leadership (self-awareness and self- regulation, task-oriented, employee concern and integrity, courageous, encouraging and supportive, being a role model, developing others, accessibility focus and personal values, empowerment and Care) on employee engagement. A hypothesis and sub- hypothesis were built; the hypotheses are presented here. 


\section{MInstitute ${ }^{\text {Mink }}$}

International Journal of Human Resource Studies

ISSN 2162-3058

2017, Vol. 7, No. 3

H2: Integrative leadership constructs strongly predict employee engagement in the private banking sector in Pakistan.

H2a: Self-awareness and Self-regulation leadership strongly predict employee engagement.

H2b: Task-Oriented leadership strongly predicts employee engagement.

H2c: Employees concern and integrity leadership strongly predict employee engagement.

H2d: Courageous leadership strongly predicts employee engagement.

H2e: Encouraging and supportive leadership strongly predicts employee engagement.

H2f: Being a role model leadership strongly predicts employee engagement.

H2g: Developing others leadership strongly predicts employee engagement.

H2h: Accessibility focus and personal values leadership strongly predicts employee engagement.

H2i: Empowerment and care leadership strongly predicts employee engagement.

Results obtained from the hierarchical regression are as follows. Overall the nine integrative leadership constructs could predict $38.2 \%$ employee engagement, of which self- awareness accounted for the highest predictive power (33.6\% as shown in table 4.8). Our model explained a $38.2 \%$ of variance in employee engagement with $F=413.707, p<.001, R^{2}=$ 38.2\%. This suggests that the model was a good fit.

The F-test on the individual construct shows whether the component impact is significantly different from zero. For each of the components, the table also reported standardized coefficients (B), R, R square, R square change and along with its significance level. The results supported the hypotheses $\mathbf{H 2 a}, \mathbf{H 2 b}, \mathbf{H 2 d}, \mathbf{H 2 e}, \mathbf{H 2 g}, \mathbf{H 2 h}$, Furthermore, the results did not support the hypotheses H2c, H2f, H2i. The results show that six constructs of integrative leadership (self-awareness/self-regulation leadership, task-oriented leadership, courageous leadership, encouraging and supportive leadership, developing others leadership, and accessibility focus and personal values leadership) returned significant at a 95\% confidence level, except three constructs (employee concern and integrity leadership, being a role model leader, and empowerment and care leadership). Therefore, it is considered that six constructs of integrative leadership significantly predict employee engagement. The results from the regression analysis are reported in table 2.

Table 2. Results of Multiple Hierarchical Regression

\begin{tabular}{|c|c|c|c|c|c|c|c|c|}
\hline \multicolumn{9}{|c|}{ Independent Variable : Employee Engagement } \\
\hline \multicolumn{9}{|c|}{ Integrative } \\
\hline Leadership & & & & $\mathrm{R}$ & R square & & & \\
\hline Constructs & Mean & SD & $\mathrm{R}$ & square & Change & (Beta) & F- Change & F-Sig \\
\hline \multicolumn{9}{|l|}{ Self- Awareness } \\
\hline /Self- Regulation & 56.74 & 10.428 & 0.58 & 0.336 & 0.336 & 0.275 & 413.707 & 0 \\
\hline Task- Oriented & 38.82 & 6.419 & 0.59 & 0.348 & 0.011 & 0.033 & 14.274 & 0 \\
\hline \multicolumn{9}{|l|}{ Employee } \\
\hline \multicolumn{9}{|l|}{ Concern and } \\
\hline Integrity & 37.23 & 7.366 & 0.59 & 0.348 & 0 & -0.159 & 0.001 & 0.982 \\
\hline
\end{tabular}




\begin{tabular}{|c|c|c|c|c|c|c|c|c|}
\hline \multicolumn{9}{|l|}{ Courageous for } \\
\hline Bank & 38.18 & 7.015 & 0.6 & 0.36 & 0.012 & 0.143 & 15.526 & 0 \\
\hline \multicolumn{9}{|l|}{ Encouraging and } \\
\hline Supportive & 37.99 & 7.034 & 0.604 & 0.365 & 0.005 & 0.125 & 6.158 & 0.013 \\
\hline \multicolumn{9}{|l|}{ Being a Role } \\
\hline Model & 29.86 & 5.267 & 0.604 & 0.365 & 0 & -0.057 & 0.23 & 0.632 \\
\hline \multicolumn{9}{|l|}{ Developing } \\
\hline Others & 14.42 & 2.756 & 0.608 & 0.37 & 0.005 & 0.105 & 6.685 & 0.01 \\
\hline \multicolumn{9}{|l|}{ Accessibility } \\
\hline \multicolumn{9}{|l|}{ Focus and } \\
\hline Personal Values & 14.29 & 2.727 & 0.616 & 0.38 & 0.01 & 0.153 & 13.069 & 0 \\
\hline \multicolumn{9}{|l|}{ Empowerment } \\
\hline and Care & 9.52 & 2.182 & 0.618 & 0.382 & 0.002 & 0.071 & 3.064 & 0.08 \\
\hline
\end{tabular}

Additionally, this study examined the differences in employee engagement among respondents' demographic characteristics. Therefore, the current study adopted a one-way analysis of variance (ANOVA). The ANOVA results presented in five parts: 1) differences in employee engagement among bank types, 2) across age groups, 3) among current bank experience groups, 4) between genders and 5) across education levels.

Employee engagement was analyzed by bank type using one-way ANOVA. The results showed that only a difference in satisfaction (dimension of employee engagement) was found, indicating that employees in conventional and Islamic banks were more satisfied than those in only Islamic and only conventional banks $(\mathrm{F}=3.142, \mathrm{p}<0.05)$. On employee engagement and other dimensions of employee engagement, no differences among bank types were found $(\mathrm{F}<1.300, \mathrm{p}>.05$, see appendix 1$)$.

.Employee engagement was analyzed across four age groups using one - way ANOVA. The results showed that only differences in satisfaction (dimension of employee engagement) were found, indicating that one group of employees (49 and over age) were more satisfied than the other three groups $(18-28,29-38,39-48)$, $(\mathrm{F}=2.826, \mathrm{p}<0.05)$. No significant difference was found in employee engagement and other dimensions of employee engagement $(p>0.05)$. The details are given in appendix 2 .

The current bank experience of employees was analysed using seven ranges (under 5 years, 6-10, 11-15, 16-20, 21-25, 26-30, 30 and above) by using one-way ANOVA. The results showed significant differences in overall employee engagement $(\mathbf{F}=\mathbf{2 . 2 2 9}, \mathbf{p}<\mathbf{0 . 0 5})$. The results also indicated that the current banking experience of the respondents did not predict differences in other dimensions of engagement ( $p>0.05)$. The details are given in appendix 3 .

Employee engagement was analyzed by education using one-way ANOVA. The results showed that employee education levels (Bachelors, Masters, MPhil and PhD) do not predict differences in employee engagement and its dimensions $(\mathrm{F}>0.01, \mathrm{p}>0.05)$. The detailed results are presented in appendix 4. 
Employee engagement was analyzed in two groups (male and female) by using one-way ANOVA. The results showed that there was no differences in the engagement level and its dimensions of male and female employees $(\mathrm{F}>0.1, \mathrm{p}>0.05)$. Indicating gender does not affect employees in private banks. The results are presented in appendix 5.

\subsection{Discussions on Study’s Results}

Current study examined the relationship of integrative leadership with employee engagement through a correlation matrix. In particular, this study found a positive relationship in the integrative leadership with employee engagement. This study also examined the predictive power of integrative leadership constructs on employee engagement. The findings of this study discovered that self-awareness and self-regulation leadership, task-oriented leadership, courageous leadership, encouraging and supportive leadership, developing others leadership, and accessibility focus and personal values leadership are main predictors of employee engagement in the private banking sector in Pakistan. Many researchers have proposed and proved that leadership plays a significant role in developing employee engagement, consequently the results of this study are akin to previously published empirical studies (Khan, Asghar \& Zaheer, 2014; Zhang et al., 2014; Anwar, 2013; Batool, 2013; Iqbal et al., 2013; Gul et al., 2012; Raja, 2012; Gul et al., 2012; Riaz, Akram \& Ijaz, 2011; Tims, Bakker \& Xanthopoulou, 2011; Xu \& Thomas, 2011; Yasin Ghadi, Fernando \& Caputi, 2011; Papalexandris \& Galanaki, 2009; Alban-Metcalfe \& Alimo-Metcalfe, 2007) in terms of relationship and prediction of leadership on employee engagement. Therefore, the findings of this study enhance the belief that integrative leadership constructs predict employee engagement. Avey, James, Hughes, Norman, and Luthan (2008) stated that leadership has a positive relationship with employee engagement. Leadership is an important element in the development of employee engagement (Ariani, 2014). Ariani (2014) stated that the drivers of employee engagement will motivate employees to be fully involved in the organization and remain committed to their work, care about the organization and their colleagues, and work on the role that exceeds role to play within the organization to ensure its success. The result of this study was supported by Social Exchange Theory. This theory suggests that employees will reciprocate the leader's behavior towards them with their own behavior and the presence of a suitable reciprocal relationship as part of a social exchange relationship development process cited in (Ariani, 2014). The results of study could add value and enhance the phenomena of integrative leadership in leadership development research and could also expand the phenomena of the theory across a different context of investigation.

Moreover, this study also found that three integrative leadership constructs (employee concern and integrity, being a role model and empowerment and care) do not significantly predict employee engagement in the private banks in Pakistan. However, there is a contradiction in the results obtained from the above-mentioned relationship of the three constructs, hence the results are dissimilar to prior studies (Anwer, 2013; Raja, 2012; Bushra, Usman \& Naveed, 2011; Gul et al., 2012). Similarly, employee concern and integrity and role modeling leadership includes the ethical aspect of leadership and both constructs did not predict employee engagement in the private banking sector in Pakistan. As a researcher, the reason for not predicting employee engagement could be that managers may be unaware or 
lack interest in practicing key ethical aspects such as integrity, being honest, avoiding unethical behavior, ethical and principled decision-making and care in the private banks in Pakistan. Many researchers claim that ethics are situation specific (Sims, 1994). Drawing on Social Exchange Theory it can be assumed that if leaders do not display behaviors such as integrity, honesty, care, avoiding unethical behavior, and ethical and principled decision-making, then he/she does not develop a social exchange relationship with followers (Blau, 1964). Similarly, if a leader performs certain effective ethical leadership behaviors, they will develop trust, respect and a positive effect on their followers, which turn, in close partnership between leaders and followers, will foster greater follower reciprocation in the form of behavior that is consistent with the leader's values (Illies, Morgeson \& Nahrgang, 2005). Likewise, empowerment and care construct did not predict employee engagement, and there could be the possibility that managers are devoid of concern and care for their employees in terms of empowerment. The target population of this study was operational staff/middle level employees. It is possible that due to their level/position in the bank, this construct might hamper the willingness of managers to empower their employees. The employee's position in the organizational hierarchy plays a more significant role in acquiring power than individual personality traits (Kanter, 1993), and empowerment is highly influenced by structural elements within the organization.

In addition, the differences in employee engagement among respondents' demographic characteristics (bank type, age, current banking experience, education and gender) were examined. This study found that bank type and age (age 49 and above) produced differences in the satisfaction dimension of employee engagement and did not indicate differences in employee engagement and its dimensions. This result is consistent with previous studies (Zhang et al., 2014; Lord \& Farrington, 2006). A possible rationale for these results, is that it is generally assumed that older people have a long-standing viewpoint regarding their job and for young people, their job is to get experience or a way to finance their short-term goals (Zhang et al., 2014). In addition, it could also reflect generational differences in attitudes of employees at work, especially attitudes attributed to younger people about not staying long with a single employer (McCrindle, 2006). Furthermore, the relationship of the current banking experience of employees was also examined through employee engagement. This study's results revealed that the current banking experience of respondents significantly affects overall employee engagement. Furthermore, it does not show any significant differences in involvement and commitment, absorption/happiness, and the energy and satisfaction dimensions of employee engagement. These results are also inconsistent with previous studies (Zhang et al., 2014). As a researcher, I believe that it is mainly attributed to the fact that the private banking sector in Pakistan has gone through a mushroom growth in the recent past. Hence, the employees do not face many problems in getting better jobs with attractive remunerations at the time of switch over. This has led to almost no effect on their employee engagement because they are better off in their new job roles and in this overall scenario, the job tenure does not affect overall employee engagement in the private banking sector in Pakistan. These contextual attributes, such as the environment covering external conditions including competitors, impact the internal functioning of the organization (Pierce $\&$ Delbecq, 1977). Therefore, different types of diversity of demographics produce different 
outcomes (Hoffman \& Maier, 1961). Previous research findings on the effects of demographic characteristics on EE have been uncertain and inconclusive (Zhang et al., 2014; Avery, Mckay \& Wilson, 2007; Robinson, Perryman \& Hayday, 2004). In conclusion, this study found the verified notion on relationship of integrative leadership with employee engagement and effect of demographic characteristics on employee engagement in the private banking sector in Pakistan.

\section{Conclusion and Recommendations}

This study confirms that leadership is a complex but influential subject and most of the styles of leadership are quite important in the context of the private banking sector in Pakistan. This study also produced evidence that certain integrative leadership constructs predict employee engagement in the private banking sector in Pakistan. It is definite that the phenomenon of leadership remains a crucial domain in the private banking sector which brings a significant change to employee's engagement. This study is to devise evidence-oriented integrative leadership nurturing leadership for tomorrow. By doing so, certain leadership roles become inevitable to motivate individual workers in the workplace to build employee involvement, commitment, satisfaction, energy, enthusiasm and passion in private banking. This study can facilitate leaders and managers to become smart leaders by identifying and adopting integrative leadership to respond to employee disengagement and develop employee engagement in their organizations.

\subsection{Theoretical and Practical Recommendation}

In this study, empirical evidence of integrative leadership constructs predict employee engagement in the private banking sector in Pakistan have been provided. Therefore, this study's findings have implication for both theory and practice. This study adds value to the literature as this study highlighted the importance and role of integrative leadership in building employee engagement for private banks in Pakistan, share the results of empirical and rigorous analysis on predictive power of integrative leadership on employee engagement. The future researcher can adopt and use this study as the foundation for further research.

The results of this study can be generalized in the boundary of private banks in Pakistan, so the key findings of this study would be of immense help to top management, supervisors and branch level managers of the private banks in Pakistan. Private bank managers can adopt integrative leadership with verified results to bring substantial change to employee engagement and to other work-related attitudes of their subordinates. This study can also be helpful to managers, leaders of different levels and HR professionals in different organizations, other banks and financial institutions can adopt this study as a foundation and can replicate it according to their respective corporate cultures.

\subsection{Recommendations for Future Research}

This study was conducted to examine the relationship and predictive power of integrative leadership with employee engagement. In future, due consideration should be given and the relationship of integrative leadership could also be examined by selecting the indicators and outcomes of employee engagement such as productivity, turnover, retention, employee's 
performance and OCB in the private banks in Pakistan. This study was about the examining the predictive power of integrative leadership on employee engagement in the private banking sector in Pakistan. Therefore, the future research should be done on other in other organizations. There is also a future need to undertake another comparative study, to examine the leadership style of high performance banks versus low performance banks. Cross cultural research is always constructive. A similar study may be conducted in other sub-continent countries such India and Bangladesh because these countries share some common cultural values with Pakistan.

\section{References}

Abbas, Q., \& Yaqoob, S. (2009). Effect of leadership development on employee performance in Pakistan. Pakistan Economic and Social Review, 47(2), 269-292.

Ahmad, N., Tariq, M. S., \& Hussain, A. (2015). Human resource practices and employee retention, evidence from the banking sector of Pakistan. Journal of Business and Management Research, 7, 186-188.

Ajaz, S., \& Mehmood, B. (2015). Job Satisfaction as a predictor of female intent-to-quit. Evidence from commercial banks of Faisalabad, Pakistan. International Journal of Academic Research in Accounting, Finance and Management Sciences, 5(3), 158-166.

Alban-Metcalfe, J., \& Alimo-Metcalfe, B. (2007). Development of a private sector version of the (Engaging) Transformational Leadership Questionnaire. Leadership \& Organization Development Journal, 28(2), 104-121. https://doi.org/10.1108/01437730710726813

Alban-Metcalfe, J., \& Alimo-Metcalfe, B. (2010). Integrative leadership, partnership working and wicked problems: a conceptual analysis. International Journal of Leadership in Public Services, 6(3), 3-13. https://doi.org/10.5042/ijlps.2010.0512

Allen, T. D., Poteet, M. L., \& Russell, J. E. (1998). Attitudes of managers who are more or less career plateaued. The Career Development Quarterly, 47(2), 159-172. https://doi.org/10.1002/j.2161-0045.1998.tb00549.x

Alvi, A. K., \& Abbasi, A. S. (2012). Impact of organizational justice on employee engagement in the banking sector of Pakistan. Middle-East. Journal of Scientific Research, 12(5), 643-649.

Annual Report of State Bank of Pakistan (2015). Statistics and data warehouse: Statistical supplement on scheduled banks of Pakistan. (Online) Available: https://www.google.com.pk/?gws_rd=cr,ssl\&ei=szDqV7H-McGTaaGUv_AF\#q=Annual+Re port+of+State+Bank+of+Pakistan+(2015) + +Statistics+and+Data+Warehouse+Statistical+sup plement+on+scheduled+banks+of+Pakistan. (February, 2016)

Antoniou, A. S., Polychroni, F., \& Vlachakis, A. N. (2006). Gender and age differences in occupational stress and professional burnout between primary and high-school teachers in Greece. Journal of Managerial Psychology, 21(7), 682-690. https://doi.org/10.1108/02683940610690213 
Ariani, D. W. (2014). Relationship leadership, employee engagement, and organizational citizenship behavior. International Journal of Business and Social Research, 4(8), 74-90.

Avery, D. R., McKay, P. F., \& Wilson, D. C. (2007). Engaging the aging workforce: the relationship between perceived age similarity, satisfaction with coworkers, and employee $\begin{array}{lllll}\text { engagement. Journal of Applied } & \text { Psychology, } & 92(6), & \end{array}$ https://doi.org/10.1037/0021-9010.92.6.1542

Avey, James B.; Hughes, Larry W.; Norman, Steven M.; and Luthans, Kyle W. (2008). Using Positivity, Transformational Leadership, and Empowerment to Combat Employee Negativity. Leadership \& Organization Development Journal, 29(2): 110-126. https://doi.org/10.1108/01437730810852470

Batista-Taran, L. C., Shuck, M. B., Gutierrez, C. C., \& Baralt, S. (2009). The role of leadership style in employee engagement. In M. S. Plakhotnik, S. M. Nielsen, \& D. M. Pane (Eds.), Proceedings of the Eighth Annual College of Education \& GSN Research Conference (pp. 15-20). Miami: Florida International University. http://coeweb.fiu.edu/research_conference/.

Batool, B. F. (2013). An empirical study on the effect of transformational leadership on organizational commitment in the banking sector of Pakistan. Journal of Business and Management, 8(2), 38-44.

Blau, P. M. (1964). Exchange and power in social life. New York: Wiley.

Bushra, F., Usman, A., \& Naveed, A. (2011). Effect of transformational leadership on employees' job satisfaction and organizational commitment in banking sector of Lahore (Pakistan). International Journal of Business and Social Science, 2(18), 261-267.

Crosby, B. C., \& Bryson, J. M. (2010). Integrative leadership and the creation and maintenance of cross-sector collaborations. The Leadership Quarterly, 21(2), 211-230. https://doi.org/10.1016/j.leaqua.2010.01.003

Crossman, A., \& Abou-Zaki, B. (2003). Job satisfaction and employee performance of Lebanese banking staff. Journal of Managerial Psychology, 18(4), 368-376. https://doi.org/10.1108/02683940310473118

Fernandez, S., Cho, Y. J., \& Perry, J. L. (2010). Exploring the link between integrated leadership and public sector performance. The Leadership Quarterly, 21(2), 308-323. https://doi.org/10.1016/j.leaqua.2010.01.009

Fernandez, S. (2005). Developing and testing an integrative framework of public sector leadership: Evidence from the public education arena. Journal of Public Administration Research and Theory, 15(2), 197-217. https://doi.org/10.1093/jopart/mui014

Fine, S., Horowitz, I., Weigler, H., \& Basis, L. (2010). Is good character good enough? The effects of situational variables on the relationship between integrity and counterproductive work behaviors. Human Resource Management Review, 20(1), 73-84. https://doi.org/10.1016/j.hrmr.2009.03.010 


\section{Mll Macrothink}

International Journal of Human Resource Studies

ISSN 2162-3058

2017, Vol. 7, No. 3

Gebauer, J., \& Lowman, D. (2008). Closing the engagement gap. How Great Companies Unlock Superior Employee Potential for Superior Results. (Online) Available: https://scholar.google.com.pk/scholar?q=Gebauer\%2C+J.\%2C+\%26+Lowman\%2C+D.+\%28 2008\%29+Closing+the+engagement+gap.+How+Great+Companies+Unlock+Superior+Empl oyee+Potential+for+Superior+Results.+\&btnG=\&hl=en\&as_sdt=0\%2C5(April 15, 2016).

Gowri, P. A., \& Mariammal, M. (2012). Factorial dimensions of employee engagement in public and private sector banks. Bonfring. International Journal of Data Mining, 2(4), 01-05. https://doi.org/10.9756/BIJDM.3065

Gul, S., Ahmad, B., Rehman, S. U., Shabir, N., \& Razzaq, N. (2012). Leadership styles, turnover intentions and the mediating role of organizational commitment. Information and Knowledge Management, 2(7), 44-51.

Gul, S., Rehman, S. U., Razzaq, N., Ahmad, B., \& Saif, N. (2012). Impact of Leadership Styles on Organizational Commitment in Pharmaceutical Companies of Pakistan. Information and Knowledge Management, 2(7), 29-36.

Hanif, F., Naqvi, S.M.M.R., \& Huassin, K. (2015). The role of employee engagement in work-related outcomes. Advances in Economics and Business, 3(6), 204-214.

Harter, J. K., Schmidt, F. L., \& Hayes, T. L. (2002). Business-unit-level relationship between employee satisfaction, employee engagement and business outcomes: A Meta-analysis. Journal of Applied Psychology, 87(2), 268-279. https://doi.org/10.1037/0021-9010.87.2.268

Hassan, M., Hassan, S., Khan, M., Ahmed, F., \& Iqbal, A. (2013). Impact of HR practices on employee satisfaction and employee loyalty: An empirical study of government owned public sector banks of Pakistan. Middle-East. Journal of Scientific Research, 16(1), 01-08.

Herbert, M. (2011). An exploration of the relationships between psychological capital (hope, optimism, self-efficacy, resilience), occupational stress, burnout and employee engagement. Master's thesis. University of Stellenbosch, South Africa.

Hoffman, L. R., \& Maier, N. R. (1961). Quality and acceptance of problem solutions by members of homogeneous and heterogeneous groups. The Journal of Abnormal and Social Psychology, 62(2), 401. https://doi.org/10.1037/h0044025

Hulin, C.L. and Smith, P.C (1965). A linear model of job satisfaction. Journal of Applied Psychology, 49(3), 209- 216. https://doi.org/10.1037/h0022164

Hunjra, A. I., Ali, M. A., Chani, M. I., Khan, H., \& Rehman, K. U. (2010). Employee voice and intent to leave: An empirical evidence of Pakistani banking sector. African Journal of Business Management, 4(14), 3056-3061.

Ilies, R., Morgeson, F. P., \& Nahrgang, J. D. (2005). Authentic leadership and eudemonic well-being: Understanding leader-follower outcomes. Leadership Quarterly, 16(3), 373-394. https://doi.org/10.1016/j.leaqua.2005.03.002

Iqbal, N., Javaid, K., Ahmad, N., \& Ateeq, M. (2013). Impact of rewards and leadership on 
employee engagement: A case study from the banking sector of Pakistan. Management and Administrative Sciences Review, 2(4), 379-390.

Jalal Sarker, S., Crossman, A., \& Chinmeteepituck, P. (2003). The relationships of age and length of service with job satisfaction: an examination of hotel employees in Thailand. $\begin{array}{lllll}\text { Journal of } & \text { Managerial } & \text { Psychology, } & 18(7), & \text { 755-758. }\end{array}$ https://doi.org/10.1108/02683940310502421

Javaid, M. F., \& Mirza, M. U. (2013). Leadership style enhances the employee organizational commitment: A Case Study of Educational Institutions in Lahore. International Journals and Conference of Management, Statistics and Social Sciences, 24. URL: http://localhost/icjmsss. Accessed on 23/04/ 2016.

Junaidi, F. (2015). Competencies for Pakistani HR Professionals. (Online) Available: https://fuwad.wordpress.com/category/issues-of-hrm-in-pakistan/page/2 (October 23, 2014) .

Kahn, W. (1990). Psychological conditions of personal engagement and disengagement at work. Academy of Management Journal, 33(4), pp. 692-724. https://doi.org/10.2307/256287

Kahn, W.A. (1992). To be fully there: psychological presence at work. Human Relations 45(4), 321-349. https://doi.org/10.1177/001872679204500402

Kanter, R.M. (1993). Men and women of the corporation (2nd ed.). New York: Basic Books.

Khan, M. A., Rehman, K., Rehman, I., Safwan, N., \& Ahmad, A. (2011). Modeling link between internal service quality in human resources management and employees retention: A case of Pakistani privatized and public sector banks. African Journal of Business Management, 5(3), 949-959.

Khan, R. I., Aslam, H. D., \& Lodhi, I. (2011). Compensation management: A strategic conduit towards achieving employee retention and job satisfaction in the banking sector of Pakistan. International Journal of Human Resource Studies, 1(1), 89. https://doi.org/10.5296/ijhrs.v1i1.809

Khan, S., Asghar, M., \& Zaheer, A. (2014). Influence of leadership style on employee job satisfaction and firm financial performance: a study of the banking sector in Islamabad, Pakistan. Актуальні проблеми економіки, 5(155), 374-384.

Khattak, J. K., Khan, M. A., Haq, A. U., Arif, M., \& Minhas, A. A. (2011). Occupational stress and burnout in Pakistan's banking sector. African Journal of Business Management, $5(3), 810-817$.

Kular, S., Gatenby, M., Rees, C., Soane, E., \& Truss, K. (2008). Employee engagement: a literature review (Working paper). Kingston Business School, Kingston University.

Lee, R. \& Wilber, E.R (1985). Age, education, job tenure, salary job characteristics and job satisfaction: A multivariate analysis. Human Relation, 38(8), pp.781-791. https://doi.org/10.1177/001872678503800806

Lord, R.J. and Farrington, P.A. (2006). Age-related differences in the motivation of 
knowledge workers. Engineering Management Journal, 18(3), 20-26. https://doi.org/10.1080/10429247.2006.11431700

Macey, W. H., \& Schneider, B. (2008). The meaning of employee engagement. Industrial and Organizational Psychology, 1(1), 3-30. https://doi.org/10.1111/j.1754-9434.2007.0002.x

Maslach, C., \& Leiter, M. P. (1997). The truth about burnout: how organization causes personal stress and what to do about it. San Francisco: Jossey-Bass.

Maslach, C., Schaufeli, W. B., \& Leiter, M. P. (2001). Job burnout. Annual Review of Psychology, 52(1), 397-422. https://doi.org/10.1146/annurev.psych.52.1.397

McCrindle, M. (2006). New generations at work: Attracting, recruiting, retaining and training generation $Y$. The ABC of XYZ. Mccridle research.

Metle, M. (1997). The relationship between age and job satisfaction: a study among female bank employees in Kuwait. International Journal of Management, 14(4), 654-66.

Mohsan, F., Nawaz, M. M., Khan, M. S., Shaukat, Z., \& Aslam, N. (2011). Are employee motivation, commitment and job involvement inter-related? Evidence from the banking sector of Pakistan. International. Journal of Business and Social Science, 2(17), 226-233.

Morse, R. S. (2010). Integrative public leadership: Catalyzing collaboration to create public value. The Leadership Quarterly, 21(2), 231-245. https://doi.org/10.1016/j.leaqua.2010.01.004

Njoroge, D. (2015). The effect of integrative leadership style on organizational commitment as moderated by employee participation in technical institutions in Kenya. Strategic Journal of Business \& Change Management, 2(4), 52-71.

Oshagbemi, T. (2000a). Is length of service related to the level of job satisfaction? International Journal of Social Economics, 27(3), 213-226. https://doi.org/10.1108/03068290010286546

Oshagbemi, T. (2000b). Gender differences in the job satisfaction of university teachers. Women in Management review, 15(7), 331-343. https://doi.org/10.1108/09649420010378133

Papalexandris, N., \& Galanaki, E. (2009). Leadership's impact on employee engagement: Differences among entrepreneurs and professional CEOs. Leadership \& Organization Development Journal, 30(4), 365-385. https://doi.org/10.1108/01437730910961685

Pierce, J. L., \& Delbecq, A. L. (1977). Organization structure, individual attitudes and innovation. Academy of Management Review, 2(1), 27-37.

Popper, M. (2005). Main principles and practices in leader development. Leadership \& organization development journal, 26(1), 62-75. https://doi.org/10.1108/01437730510575598

Raja, M. W. (2012). Does transformational leadership lead to higher employee work engagement: A study of Pakistani service sector firms? International. Journal of Academic Research in Business and Social Sciences, 2(1), 160-166. 
Rasheed, A., Khan, S., \& Ramzan, M. (2013). Antecedents and consequences of employee engagement: The case of Pakistan. Journal of Business Studies Quarterly, 4(4), 183-200.

Rashidi, A.A., Rahman, M.U. (2013). Retention Issues in Banking Industry of Pakistan: A Case Study of Habib Metro and Soneri Bank. JISR-MSSE, 1(11), 57-66.

Riaz, T., Akram, M. U., \& Ijaz, H. (2011). Impact of transformational leadership style on affective employee's commitment: An empirical study of the banking sector in Islamabad (Pakistan). The Journal of Commerce, 3(1), 43-51.

Robinson, D., Perryman, S. and Hayday, S. (2004). The Drivers of Employee Engagement (Report). Institute for Employment Studies, Brighton.

Rothbard, N. P. (2001). Enriching or depleting? The dynamics of engagement in work and family roles. Administrative Science Quarterly, 46(4), 655-684. https://doi.org/10.2307/3094827

Saks, A. M. (2006). Antecedents and consequences of employee engagement. Journal of Managerial Psychology, 21(7), 600-619. https://doi.org/10.1108/02683940610690169

Saleem, I., Hussain S.A., \& Saleem A. (2012). Factors affecting job satisfaction of Pakistani bankers. Journal of Business Strategies, 6(2), 21-29.

Savery, L. K. (1996). The congruence between the importance of job satisfaction and the perceived level of achievement. Journal of Management Development, 15(6), 18-27. https://doi.org/10.1108/02621719610120110

Schaufeli, W.B., Salanova, M., Gonzalez-Roma, V., \& Bakker, A.B. (2002). The measurement of engagement and burnout: a confirmative analytic approach. Journal of Happiness Studies 3(1), 71-92. https://doi.org/10.1023/A:1015630930326

Seijts, G. H., \& Crim, D. (2006). What engages employees the most or, the ten C's of employee engagement. Ivey Business Journal, 70(4), 1-5.

Shaikh, S. S., Akaraborworn, C., \& Sorod, B. (2017). Development of the integrative leadership measure and its validation on employee engagement in the private sector in Pakistan. Doctoral dissertation. National Institute of Development Administration, Bangkok, Thailand.

Shuck, B. (2011). Integrative literature review: Four emerging perspectives of employee engagement: an integrative literature review. Human Resource Development Review, 10(3), 304-328. https://doi.org/10.1177/1534484311410840

Shuck, B., \& Wollard, K. (2010). Employee engagement and HRD: A seminal review of the foundations. Human Resource Development Review, 9(1), 89-110. https://doi.org/10.1177/1534484309353560

Siegel, P. G. (2013). Ethical leadership and organizational commitment in the Canadian Armed Forces: an analysis of perceived supervisor ethical leadership as a predictor of organizational commitment in a Canadian Armed Forces sample (Master's thesis). Saint 
Mary's University, Halifax, Nova Scotia.

Silvia, C., \& McGuire, M. (2010). Leading public sector networks: An empirical examination of integrative leadership behaviors. The Leadership Quarterly, 21(2), 264-277. https://doi.org/10.1016/j.leaqua.2010.01.006

Simpson, M.R. (2009). Engagement at work: A review literature. International Journal of Nursing Studies, 46(7), 1012-1024. https://doi.org/10.1016/j.ijnurstu.2008.05.003

Sims, R. R. (1994). Ethics and organizational decision making: A call for renewal. Greenwood Publishing Group.

Tims, M., Bakker, A. B., \& Xanthopoulou, D. (2011). Do transformational leaders enhance their followers' daily work engagement? The Leadership Quarterly, 22(1), 121-131. https://doi.org/10.1016/j.leaqua.2010.12.011

Tomlinson, G. (2010). Building a culture of high employee engagement. Strategic HR Review, 9(3), 25-31. https://doi.org/10.1108/14754391011040046

Vance, R. J. (2006). Employee Engagement and Commitment: A Guide to Understanding. Measuring and Increasing Engagement in Your Organization (1st ed.). SHRM Foundation, Alexandria, 45.

Van Foeken, M. J. (2010). The Effects of Charismatic Leadership, Ethical Leadership, Sustainable Leadership, and Authentic Leadership on Employee Outcomes Mediated by Value Congruence (Unpublished master's thesis). University of Amsterdam Business School, Netherlands.

Van Wart, M. (2005). Dynamics of leadership in public service: Theory and practice. Armonk, New York: ME Sharpe.

Xu, J., \& Cooper Thomas, H. (2011). How can leaders achieve high employee engagement? Leadership \& Organization Development Journal, 32(4), 399-416. https://doi.org/10.1108/01437731111134661

Yasin Ghadi, M., Fernando, M., \& Caputi, P. (2013). Transformational leadership and work engagement: The mediating effect of meaning in work. Leadership \& Organization Development Journal, 34(6), 532-550. https://doi.org/10.1108/LODJ-10-2011-0110

Yukl, G. (2010). Leadership in Organizations ( $7^{\text {th }}$ ed.). Upper Saddle River, NJ: Prentice Hall. Yukl, G. (2002). Leadership in organizations $\left(5^{\text {th }}\right.$ ed). Upper Saddle River, NJ: Prentice Hall.

Zhang, T., C. Avery, G., Bergsteiner, H., \& More, E. (2014). The relationship between leadership paradigms and employee engagement. Journal of Global Responsibility, 5(1), 4-21. https://doi.org/10.1108/JGR-02-2014-0006

4-Consulting and DTZ Consulting \& Research. (2007). Employee engagement in the public sector: a review of literature. Online Available: www.scotland.gov.uk/Resource/Doc/176883/0049990.pdf (February 27, 2016). 


\section{Appendix}

Appendix 1. Results from ANOVA on Employee Engagement among Bank types.

\begin{tabular}{|c|c|c|c|c|c|c|c|}
\hline \multirow[t]{2}{*}{$\begin{array}{l}\text { Dependent } \\
\text { Variable }\end{array}$} & $\begin{array}{l}\text { No of } \\
\text { Banks }\end{array}$ & Bank Type & $\begin{array}{c}\text { Mean } \\
\text { (10 Items) }\end{array}$ & SD & $\begin{array}{c}\text { S. } \\
\text { Error }\end{array}$ & $\begin{array}{c}\quad \text { F } \\
\text { statistics }\end{array}$ & Sig \\
\hline & 246 & Islamic & 39.07 & 7.338 & 0.468 & 0.379 & 0.685 \\
\hline \multirow{4}{*}{$\begin{array}{l}\text { Employee } \\
\text { Engagement }\end{array}$} & 170 & Conventional & 39.47 & 7.123 & 0.546 & & \\
\hline & & Islamic and & & & & & \\
\hline & 368 & Conventional & 39.58 & 7.214 & 0.376 & & \\
\hline & 255 & Islamic & 9.69 & 1.971 & 0.123 & 0.379 & 0.685 \\
\hline \multirow{5}{*}{$\begin{array}{l}\text { Absorption and } \\
\text { Happiness }\end{array}$} & 175 & Conventional & 9.74 & 2.147 & 0.162 & & \\
\hline & & Islamic and & & & & & \\
\hline & 381 & Conventional & 9.59 & 2.019 & 0.103 & & \\
\hline & 252 & Islamic & 14.62 & 3.151 & 0.198 & 1.267 & 0.282 \\
\hline & 174 & Conventional & 14.39 & 3.069 & 0.233 & & \\
\hline \multirow[t]{3}{*}{ Energy } & & Islamic and & & & & & \\
\hline & 376 & Conventional & 14.82 & 3.006 & 0.155 & & \\
\hline & 253 & Islamic & 14.67 & 2.773 & 0.174 & 0.144 & 0.866 \\
\hline \multirow{4}{*}{$\begin{array}{l}\text { Involvement } \\
\text { and } \\
\text { Commitment }\end{array}$} & 172 & $\begin{array}{l}\text { Conventional } \\
\text { Islamic and }\end{array}$ & 14.81 & 2.843 & 0.217 & & \\
\hline & 382 & Conventional & 14.74 & 2.725 & 0.139 & & \\
\hline & 251 & Islamic & 9.72 & 2.153 & 0.136 & 3.142 & 0.044 \\
\hline & 177 & Conventional & 10.16 & 2.012 & 0.151 & & \\
\hline \multirow[t]{2}{*}{ Satisfaction } & & Islamic and & & & & & \\
\hline & 383 & Conventional & 10.07 & 2.017 & 0.103 & & \\
\hline
\end{tabular}




\section{Macrothink \\ International Journal of Human Resource Studies \\ ISSN 2162-3058 2017, Vol. 7, No. 3}

Appendix 2. Results from ANOVA on Employee Engagement across Age Groups

\begin{tabular}{|c|c|c|c|c|c|c|c|}
\hline \multirow[t]{2}{*}{ Dependent Variable } & $\begin{array}{c}\text { No of } \\
\text { Respondents }\end{array}$ & $\begin{array}{c}\text { Age } \\
\text { Groups }\end{array}$ & $\begin{array}{c}\text { Mean } \\
(10 \\
\text { Items })\end{array}$ & SD & $\begin{array}{c}\text { S. } \\
\text { Error }\end{array}$ & $\begin{array}{c}\text { F } \\
\text { Statistics }\end{array}$ & Sig \\
\hline & 303 & 18 to 28 & 39.29 & 7.273 & 0.418 & 2.558 & 0.054 \\
\hline Employee & 351 & 29 to 38 & 39.02 & 7.521 & 0.401 & & \\
\hline \multirow[t]{3}{*}{ Engagement } & 87 & 39 to 48 & 40.01 & 6.419 & 0.688 & & \\
\hline & 30 & 49 and above & 42.63 & 5.027 & 0.918 & & \\
\hline & 313 & 18 to 28 & 9.65 & 1.941 & 0.11 & 0.459 & 0.711 \\
\hline \multirow{3}{*}{$\begin{array}{l}\text { Absorption and } \\
\text { Happiness }\end{array}$} & 361 & 29 to 38 & 9.57 & 2.163 & 0.114 & & \\
\hline & 91 & 39 to 48 & 9.78 & 1.89 & 0.198 & & \\
\hline & 32 & 49 and above & 9.91 & 1.838 & 0.325 & & \\
\hline \multirow{5}{*}{ Energy } & & & & & & 2.569 & 0.053 \\
\hline & 309 & 18 to 28 & 14.74 & 3.051 & 0.174 & & \\
\hline & 358 & 29 to 38 & 14.42 & 3.2 & 0.169 & & \\
\hline & 90 & 39 to 48 & 14.89 & 2.85 & 0.3 & & \\
\hline & 31 & 49 and above & 15.87 & 2.094 & 0.376 & & \\
\hline \multirow{4}{*}{$\begin{array}{l}\text { Involvement and } \\
\text { Commitment }\end{array}$} & 314 & 18 to 28 & 14.65 & 2.801 & 0.158 & 2.443 & 0.063 \\
\hline & 359 & 29 to 38 & 14.60 & 2.87 & 0.151 & & \\
\hline & 90 & 39 to 48 & 15.02 & 2.454 & 0.259 & & \\
\hline & 30 & 49 and above & 15.9 & 1.936 & 0.353 & & \\
\hline \multirow{4}{*}{ Satisfaction } & 314 & 18 to 28 & 9.84 & 2.144 & 0.121 & 2.826 & 0.038 \\
\hline & 363 & 29 to 38 & 9.98 & 2.063 & 0.108 & & \\
\hline & 89 & 39 to 48 & 10.19 & 1.924 & 0.204 & & \\
\hline & 32 & 49 and above & 10.88 & 1.431 & 0.253 & & \\
\hline
\end{tabular}


Appendix 3. Results from ANOVA on Employee Engagement across Current Bank Experience Groups

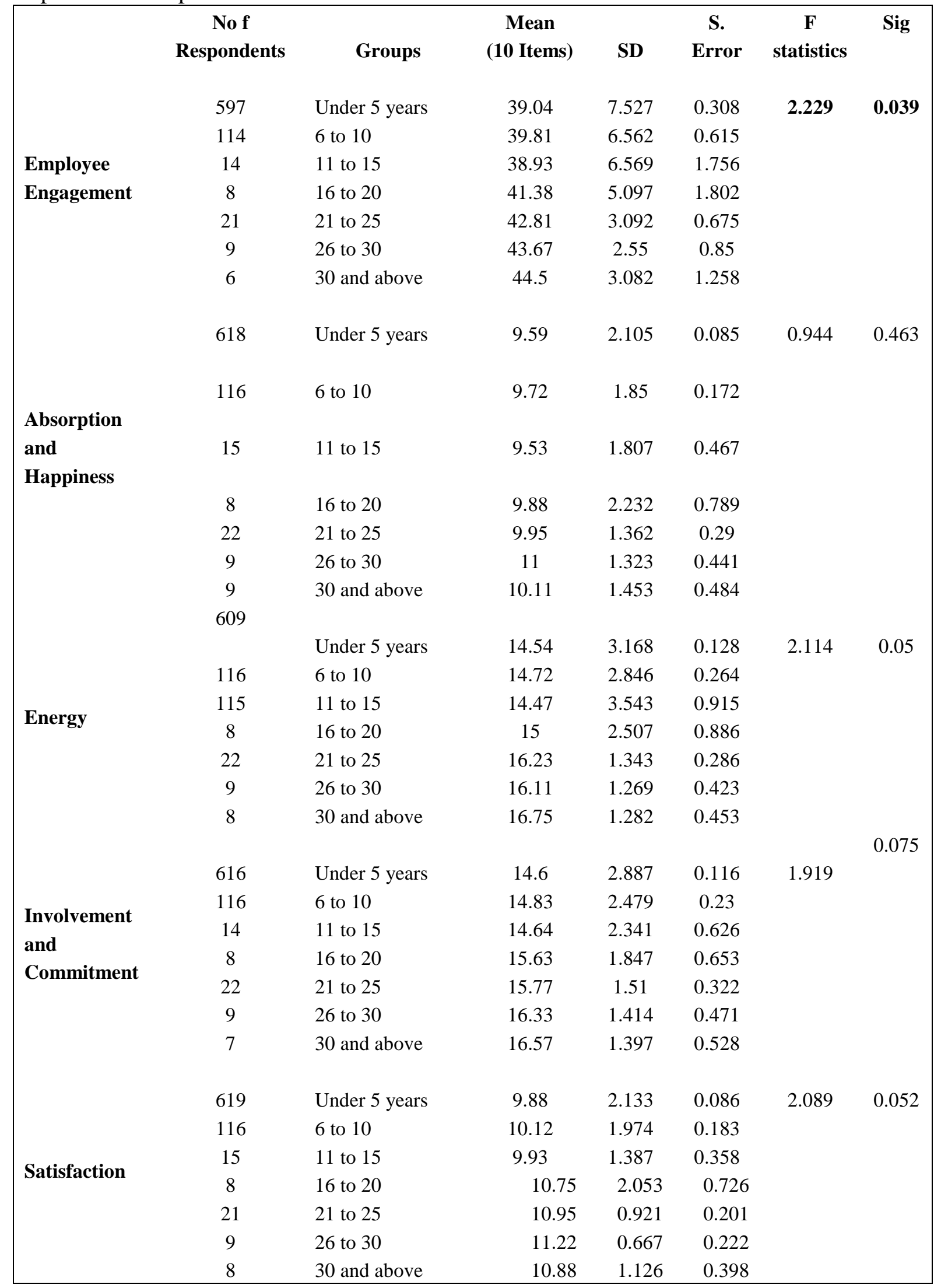


Appendix 4. Results from ANOVA on Employee Engagement across Education Levels

\begin{tabular}{|c|c|c|c|c|c|c|c|}
\hline & $\begin{array}{l}\text { Number of } \\
\text { Respondents }\end{array}$ & $\begin{array}{c}\text { Education } \\
\text { Level }\end{array}$ & $\begin{array}{c}\text { Mean } \\
\text { (10 Items) }\end{array}$ & SD & S. Error & $\begin{array}{c}\text { F } \\
\text { statistics }\end{array}$ & Sig \\
\hline Employee & 250 & Bachelors & 39.64 & 7.006 & 0.443 & 0.293 & 0.746 \\
\hline \multirow[t]{2}{*}{ Engagement } & 513 & Masters & 39.27 & 7.328 & 0.324 & & \\
\hline & 8 & MPhil and above & 38.38 & 9.97 & 3.525 & & \\
\hline \multirow{4}{*}{$\begin{array}{l}\text { Absorption } \\
\text { and } \\
\text { Happiness }\end{array}$} & 263 & Bachelors & 9.75 & 1.99 & 0.123 & 0.842 & 0.431 \\
\hline & 528 & Masters & 9.60 & 2.054 & 0.089 & & \\
\hline & 7 & & & & & & \\
\hline & & MPhil and above & 9.00 & 2.582 & 0.976 & & \\
\hline \multirow{3}{*}{ Energy } & 255 & Bachelors & 14.90 & 2.907 & 0.182 & 1.237 & 0.291 \\
\hline & 526 & Masters & 14.54 & 3.139 & 0.137 & & \\
\hline & 8 & MPhil and above & 14.25 & 3.955 & 1.398 & & \\
\hline \multirow{4}{*}{$\begin{array}{l}\text { Involvement } \\
\text { and } \\
\text { Commitment }\end{array}$} & 261 & Bachelors & 14.64 & 2.705 & 0.167 & 0.378 & 0.685 \\
\hline & 525 & Masters & 14.77 & 2.799 & 0.122 & & \\
\hline & & & & & & & \\
\hline & 8 & MPhil and above & 14.13 & 3.523 & 1.246 & & \\
\hline \multirow[t]{3}{*}{ Satisfaction } & 264 & Bachelors & 9.94 & 2.139 & 0.132 & 0.081 & 0.923 \\
\hline & 526 & Masters & 10.00 & 2.017 & 0.088 & & \\
\hline & 8 & MPhil and above & 10.00 & 2.976 & 1.052 & & \\
\hline
\end{tabular}

Appendix 5. Results from ANOVA on Employee Engagement according to Gender

\begin{tabular}{lclccccc}
\hline & $\begin{array}{c}\text { No of } \\
\text { Respondents }\end{array}$ & Gender & $\begin{array}{c}\text { Mean } \\
(\mathbf{1 0} \text { Items })\end{array}$ & SD & Mean & T & Sig \\
\hline Employee & 637 & Male & 39.45 & 7.212 & 0.286 & 0.289 & 0.773 \\
Engagement & 143 & Female & 39.26 & 7.294 & 0.61 & & \\
\hline Absorption and & 657 & Male & 9.69 & 1.999 & 0.078 & 1.208 & 0.227 \\
Happiness & 149 & Female & 9.47 & 2.173 & 0.178 & & \\
\hline Energetic & 650 & Male & 14.70 & 3.051 & 0.12 & 0.597 & 0.551 \\
Involvement & 147 & Female & 14.54 & 3.141 & 0.259 & & \\
and & 655 & Male & 14.72 & 2.778 & 0.109 & -0.337 & 0.736 \\
Commitment & 148 & & & & & \\
\hline \multirow{2}{*}{ Satisfaction } & 660 & Male & 10.00 & 2.057 & 0.08 & 0.327 & 0.744 \\
\hline
\end{tabular}

\section{Copyright Disclaimer}

Copyright for this article is retained by the author(s), with first publication rights granted to the journal.

This is an open-access article distributed under the terms and conditions of the Creative Commons Attribution license (http://creativecommons.org/licenses/by/4.0/). 